\title{
Kansantanssi-käsitteen sisältö suomalaisten maailmankuvassa
}

Jokainen kansanperinteen opiskelija kohtaa jossain vaiheessa ongelman, minkälainen sisältö tulisi antaa kansan-alkuisille käsitteille. Tarkoitukseni on tässä artikkelissa tulkita kansantanssin sisältöä sekä julkaistun määritelmän että haastattelupuheen kautta. ${ }^{1}$

Artikkelissa esittelen kansantanssin diskursiivisena puhetapana. ${ }^{2}$ Aluksi tulkitsen kansantanssidiskurssin esiin kansainvälisestä kansantanssimääritelmästä ja myöhemmin suomalaisesta kansantanssi-aiheisesta haastattelupuheesta. Artikkeli on pyrkimys pureutua suomalaisten kansantanssikäsityksiin eli esittelen myös haastattelututkielmani tuloksia viitekehyksineen ja metodeineen. Haastattelupuheen kansantanssi-käsiteanalyysin pohjalta olen tehnyt kaksi typologisointia. Esittelen kansantanssin merkitystyypit sekä informanttien tanssia koskevien maailmankuvien pohjalta tehdyn typologian.

1 Tämä esitys pohjautuu osittain pro gradu -tutkielmaani 'Kansantanssi puheena Suomessa 1990-luvulla". Tampereen yliopiston kansanperinteen laitos, 1993.

2 'Diskurssi'-käsite on peräisin Stuart Hallilta. Hall kertoo: 'Diskurssi on ryhmä lausumia, jotka tarjoavat kielen sitä varten, että voitaisiin puhua tietynlaisesta jotakin aihetta koskevasta tiedosta - toisin sanoen representoida tätä tietoa. Kun lausumia jostakin aiheesta esitetään jonkin erityisen diskurssin sisällä, diskurssi mahdollistaa aiheen näkemisen jollakin tietyllä tavalla. Se myös rajoittaa muita tapoja, joilla aihe voitaisiin esittää. (Hall 1992, 291 siteerannut Lehtonen 1994, 110.)

Diskurssin muodostavia ilmauksia puolestaan säätelee tietty 'diskursiivinen' käytäntö. Hall tiivistää asian seuraavasti: 'Diskursiiviset muodostumat 'muotoilevat' omat tiedon kohteensa ja subjektinsa. Niillä on oma käsitejärjestelmänsä, ne noudattavat omaa logiikkaansa ja toimivat omien ilmaisumuotojensa avulla sekä luovat oman tapansa tunnistaa mikä on 'totta' ja sulkevat pois mikä on 'virheellistä' niiden oman totuusjärjestelmän puitteissa. Ne luovat säännöillään 'tilan', jossa tietyt väitteet voidaan ilmaista." (Hall 1992, 345 siteerannut Lehtonen 1994, 110.) 


\section{"Kansantanssi-diskurssi"}

Tanssi on kommunikointia. Tanssi siis välittää viestejä ja uusintaa kulttuurissamme vallitsevia ajatusmuotoja. Tanssia on siten mahdollista lähestyä "tekstinä". Kaikki teksti on tuotettu jonkin diskurssin sisällä. Kansantanssi tanssina ja kansantanssista puhuminenkin ovat diskursiivista puhetta ja kutsun tätä puhetapaa "kansantanssidiskurssiksi".

Kansantanssi koetaan kansallisena kulttuurina. Ilmeisesti kansallista identiteettiä ei voi luoda ilman "toista". Kansantanssinkin avulla tuotetaan käsitys "meistä" ja "muista". (Ks. Anttila 1993, 108; Lehtonen 1994, 96; Rantonen 1994, 131.)

Kansantanssi-diskurssi on mahdollista tunnistaa omaksi erityiseksi "me ja muut" -diskurssiksi, joka on tapa representoida todellisuutta. Yritän seuraavaksi tulkita 1960-luvun eurooppalaisesta kansantanssimääritelmästä esiin siinä olevan "me ja muut" -diskurssin eli tietyn representaation todellisuudesta.

\section{Kansantanssi-diskurssi kansantanssimääritelmässä}

Kansan-alkuisten ${ }^{3}$ sanojen sisällön ongelmaa on pohdittu sekä Suomessa että kansainvälisillä näyttämöillä. Yksi dokumentti tällaisista keskusteluista on Felix Hoerburgerin raportti "International Folk Music Council'in" kokouksesta vuodelta 1968. Siellä kansantanssi-käsitteen sisällöstä sovittiin, että kansantanssilla on kaksi olomuotoa. Ensimmäisen olomuodon mukaisiin ominaisuuksiin kuuluu, että kansantanssi on erottamaton osa yhteisönsä elämää. Tanssi on altis muutoksille eli se on luonteeltaan improvisatorista ja spontaania. Tanssi opitaan matkimalla.

Kansantanssi-käsitteen toisen olomuodon ominaisuudet ovat edellisille vastakohtaisia. Sen mukaan kansantanssi on yhteisön jäsenille vain vapaa-ajan viettoa, harrastusta, liikuntaa ja värikäs näytelmä. Tällaisella kansantanssilla on vakioidut koreografiat ja ne opitaan organisoidun opetuksen avulla. Hoerburger toteaa lisäksi, että 1960-luvun Länsi-Euroopassa ei arveltu enää esiintyvän ensimmäisen olomuodon mukaista tanssia. (1968, 30-33.)

Määritelmä ilmoittaa, että länsieurooppalaisille kansantanssi on vain harrastamista, kun taas muualla kansantanssi on osa elämää. Näkemys on helppo osoittaa eurosentristiseksi ja jopa rasistiseksi. Määritelmässä on sisäänkirjoitettuna ajatus, että vain eurooppalaiset ovat 'kehittyneitä", koska vain he hallitsevat vakioidut koreografiat ja organisoidun opetuksen. Määritelmä ei anna "muille" mahdollisuutta olla tasaveroisia. Todellisuudessa sekä tansseilla että

3 Tämä osa artikkelista on julkaistu aikaisemmin Uusi Kansanmusiikki -lehdessä numerossa $1994 / 3,46-47$. 
kansoilla lienee samankaltaisia piirteitä maailmanlaajuisesti: niin meillä kuin muillakin on käytössään monenlaisia tansseja, joilla on vaihtelevat merkitykset.

\section{Kansantanssi puheena Suomessa -tutkimus}

Kansantanssi-käsitteen sisällönmäärittely on ongelmallista. Edellä esitelty kansainvälinen määritelmäkin on tästä oiva todiste. Sisällönmäärittelyongelma mielessäni menin ' kentälle". Halusin kerätä suomalaista kansantanssipuhetta ja eritellä puhetta kognitiivisen etnomusikologian näkökulmasta. Tutkimustehtäväni oli eritellä informanttien tanssikognitioita. Tanssikognitiot purkaantuivat typologioiksi. Esittelen seuraavaksi viitekehyksen ja tutkimusaineiston hankintametodeineen.

Kognitiivisen musiikkiantropologian tutkimuskenttä tanssin tutkimukseen sovellettuna

Musiikkiantropologiaa kiinnostavat musiikin ja kulttuurin väliset vaikutussuhteet. Tällöin tutkimusintressejä on kaksi: miten musiikki ilmenee kulttuurissa ja miten kulttuuri ilmenee musiikissa. Näkökulma edellyttää laajennoksia Merriamin tutkimusmalliin ihmisen ja kulttuurin osalta. Moisala rakentaa Geertzin, Murdockin ja Merriamin avulla tutkimusviitekehyksen, joka visualisoi tiivistetyssä muodossa koko musiikkiantropologian tutkimuskentän. (Moisala 1991, 118.) (Ks. kaavio 1.) Moisala on kehitellyt teorian musiikintutkimuksen tarpeisiin. Tutkielmassani sovellan sitä tanssintutkimukseen. Mielestäni tanssia voi lähestyä kulttuurina samoin kuin musiikkiakin.

Pirkko Moisala toteaa artikkelissaan "Musiikkikulttuurin kognitiivinen viitekehys" (1988), että Alan Merriamin kolmitasoinen 'käsitykset-käyttäytyminen-tuote' -tutkimusmalli tarjoaa mielekkään pohjan musiikkikulttuurin kognitiivisen viitekehyksen soveltamiselle. "Kognitiivisessa etnomusikologias$\mathrm{sa}^{\text {"4 }}$ kiinnostus kohdistuu Merriamin tutkimusmallin 'käsitykset'-tasoon. (Mts. 146-147.) Merriamin mielestä musiikin käsitteellistäminen koskettelee kysymyksiä siitä, mitä musiikki on tai mitä sen tulisi olla, mistä musiikki on peräisin ja mitkä ovat inhimillisen musikaalisuuden lähteet $(1964,33)$. Musiikkikognition käsitteen ajatellaan sen sijaan sisältävän kaikki musiikkikulttuurin kogni-

\footnotetext{
4 Vuonna 1988 Moisalan mielestä kognitiivisesta etnomusikologiasta ei vielä voitu puhua ilman lainausmerkkejä. Vuoden 1993 artikkelissa "Kulttuurisen musiikin kognitiivinen tutkimus" lainausmerkit jäävät pois eli Moisalan mielestä kognitiivinen etnomusikologia täyttää oman erillisen koulukunnan kriteerit (Moisala 1993, 50-74).
} 
tiiviset piirteet, myös musiikin tekemisen, säveltämisen, esittämisen ja vastaanottamisen kognitiiviset prosessit. (Moisala 1988, 150.)

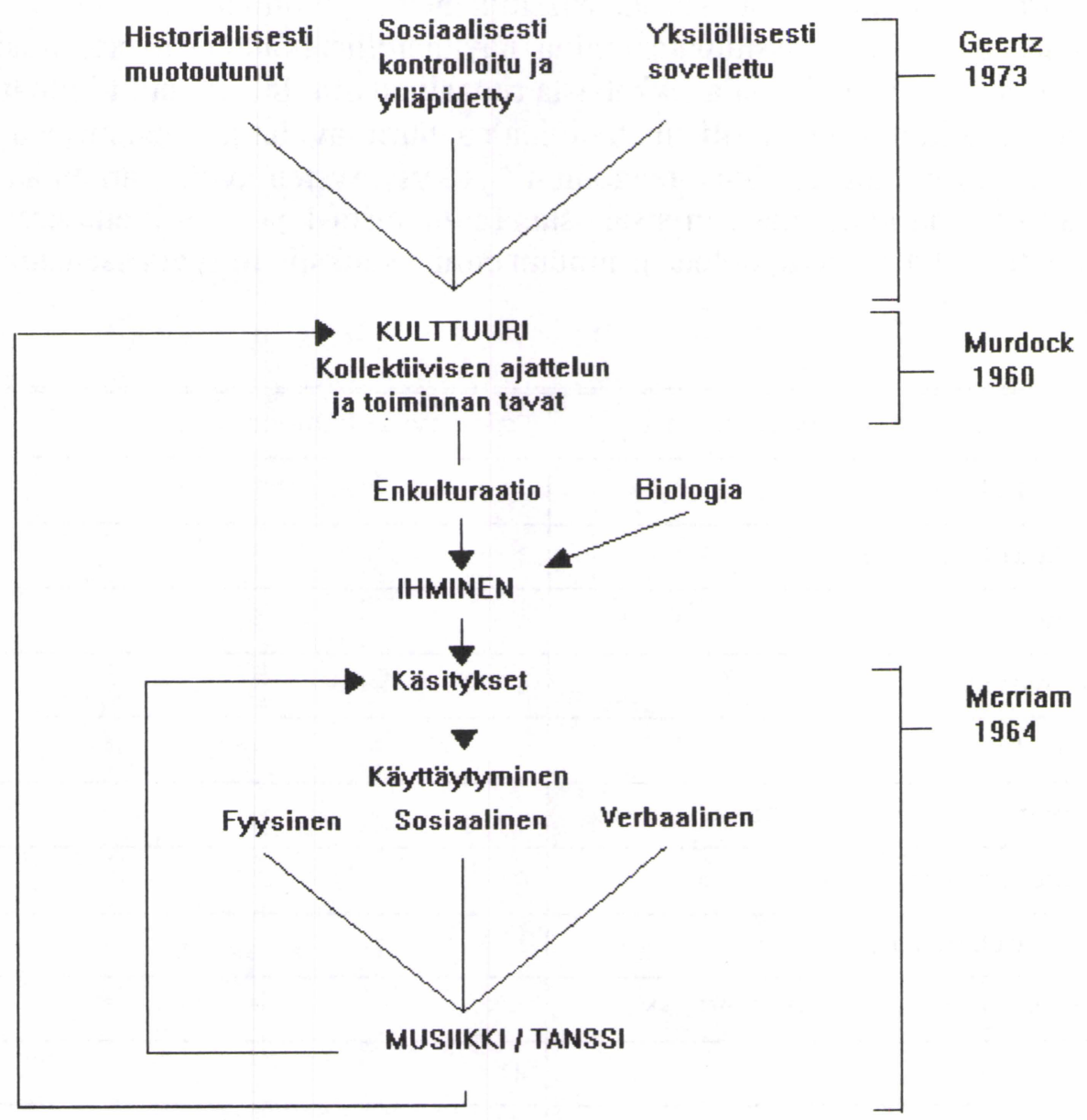

Kaavio 1. Musiikin ja tanssin suhde kulttuuriin. (Moisala 1991, 19; tanssi-sanan lisäys kirjoittajan oma.)

\section{Tutkimusaineisto}

Olen tutkinut suomalaisten kansantanssi-käsitystä ja siihen liittyvää maailmankuvaa sadan satunnaisotannalla valitun haastattelun avulla. Satunnaisotannan tein yhdentoista suomalaisen kaupungin kesätoreilta vuonna 1992. Haastatteluaineistoa kertyi kaksitoista tuntia ja haastateltavia oli yhteensä sata.

Keskeisiä teema-alueita oli mielestäni tehokkainta lähestyä ns. teemahaastattelu- ja kuvamenetelmää soveltamalla. Käytännössä haastattelin informanttejani nauhurin, kysymyspaperin ja kuvakokoelman kanssa. Kysymyspa- 
peri palveli lähinnä muistilappuna, jotta kaikki etukäteen mietityt teemat tulisivat käsiteltyä. Kysymysten muotoilua vaihtelin tilannekohtaisesti. Kuvakokoelma sisälsi kuusi tanssiaiheista kuvaa. Tutkijanäkökulmasta katsottuna kuvat esittivät kuutta erilaista kansantanssitilannetta: "suomalaista" lavatanssia, nuorison diskoilua, tanssitupatanhuilua, näyttämöllistä tanhuesitystä, brasilialaista sambakarnevaalia ja afrikkalaista rituaalitanssia. Informantin kohtaustilanteessa tarkoituksenani oli siis taltioida nauhurin avulla ja päiväkirjaan kirjaamalla informanttien "kuvareagoinnit" ja kysymysten avulla tarkentaa yhteistä tulkintaa kansantanssin sisällöstä. Taulukoista 1 ja 2 on luettavissa informanttien ikään, sukupuoleen ja muihin ominaisuuksiin liittyviä useuslukuja. (Ks. taulukot 1 ja 2.)

\begin{tabular}{||l|l||}
\hline Informanttien ominaisuuksia & Esiintymistiheys \\
\hline mustalainen & 2 \\
\hline ruotsinkielinen & 3 \\
\hline saamelainen & 1 \\
\hline uskovainen & 4 \\
\hline teosofi & 1 \\
\hline kansantanssinharrastaja & 3 \\
\hline tanssinharrastaja & 4 \\
\hline ammattitanssija & 1 \\
\hline ASENNE HAASTATTELUA KOHTAAN: & \\
\hline innokas & 21 \\
\hline kohtelias & 70 \\
\hline torjuva & 9 \\
\hline
\end{tabular}

Taulukko 1. Informanttien ominaisuuksia useuslukuineen. 


\begin{tabular}{||l|l|l||}
\hline ikä & miehiä & naisia \\
\hline \hline alle 20 vuotta & 8 & 4 \\
\hline $20-30$ vuotta & 17 & 10 \\
\hline $30-40$ vuotta & 2 & 4 \\
\hline $40-50$ vuotta & 15 & 9 \\
\hline $50-60$ vuotta & 9 & 11 \\
\hline $60-70$ vuotta & 2 & 3 \\
\hline yli 70 vuotta & 4 & 2 \\
\hline \hline yhteensä & 43 & 57 \\
\hline \hline
\end{tabular}

Taulukko 2. Informanttien ikä- ja sukupuolijakaumat useuslukuineen.

\section{Kansantanssin merkitystyypit}

Vertailtuani informanttien tanssikäsityksiä havaitsin heidän erittelevän tanssi-ilmiötä joko tanssin iästä tai sen tehtävästä käsin. Seuraavaksi muotoilin ikään ja funktioon pohjautuvan nelikentän. (Ks. kaavio 2.) Tanssin tehtävä -akselin ääripäät ovat tanssi seurusteluna ja tanssi näyttämölle nostettuna. Ikä-akselin ääripäät ovat luonnollisesti uusi ja vanha tanssi. Mielestäni mikä tahansa yksittäinen tanssi on sijoitettavissa iän ja tehtävän määrittämään universumiin. Informanttieni esittelemät kansantanssin merkityssisällöt piirtyivät nelikentälle aluekuvioina. Kolme korostusta on mahdollista abstrahoida ympyräkuvioiksi kuitenkin siten, että ympyröiden sijainnit nelikentällä vaihtelevat korostuksista riippuen. Yksi korostus piirtyy ellipsikuvioina ja ellipsin sijainti on nelikentän yläosassa.

Informanttien tanssipuheesta oli mahdollista löytää neljänlaisia kansantanssin merkitystyyppejä. Tanssi voi kuulua kansantanssi -käsitteen piiriin, jos se on tunnistettavissa (1) estraditaiteeksi (2) perinteeseen sitoutuvaksi (3) etniseksi tai (4) rahvaan kulttuuriksi. 
1. RAHVAAN TANSSI - KOROSTUS

Tanssin tehtävä

Esittämistä

Tanssin ik

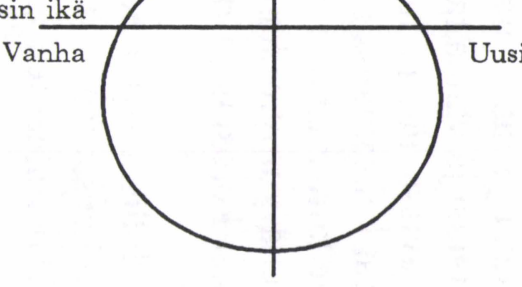

Seurustelua, ilonpitoa

2. ESTRADITAIDE - KOROSTUS

Tanssin tehtävä

Esittämistä

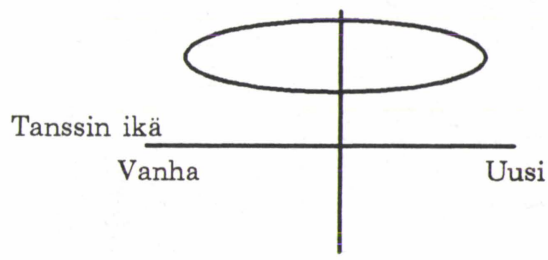

3. ETNINEN TANSSI - KOROSTUS

Tanssin tehtävä

Esittämistä

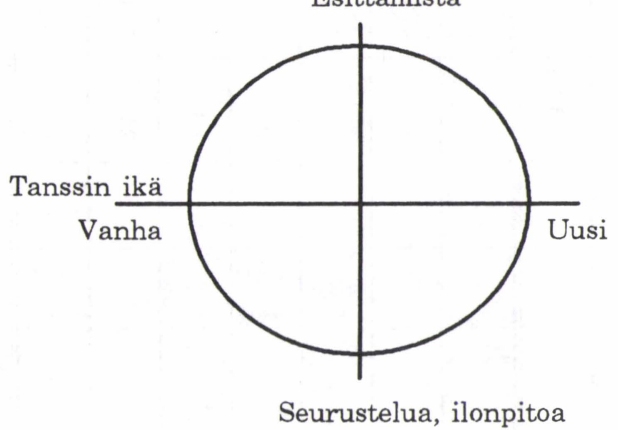

Seurustelua, ilonpitoa

4. PERINTEINEN TANSSI - KOROSTUS

Tanssin tehtävä

Esittämistä

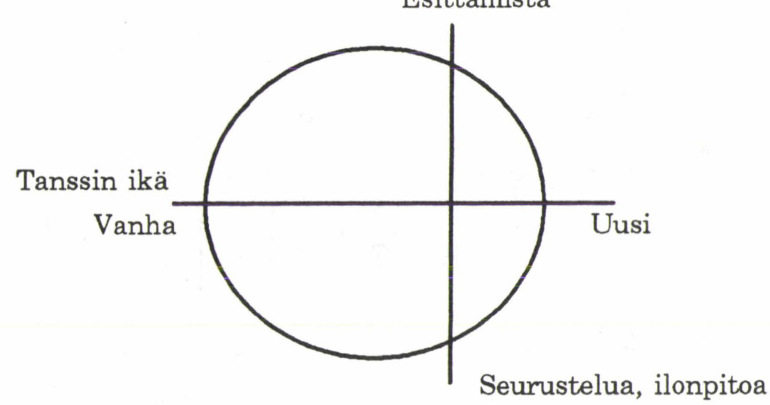


Osa informanteista (27 prosenttia) kuvasi kansantanssin ominaisuuksia luetellessaan kansantanssin olevan nimenomaan kansallispukuihin pukeutuneiden tanssijoiden esiintymistä näyttämöllä. Tanssijat ovat harjoittelemalla kehittäneet tanssitaitoaan ja siten esiintymiset ovat luonteeltaan taitotanssiesityksiä. Kansallispukujen käyttö tukee esteettisiä tavoitteita. Kansallispuvut koetaan viehättävinä ja eksoottisina. Kansantanssi on siis taidemuoto. Estradi-kansantanssia tanssii harrastaja, joka halutessaan hyödyntää perinnettä esteettisesti tai myös ideologisesti, poliittisesti ja kaupallisesti. Harrastaja ei vain esitä lavalla vanhaa tai uutta tanssia, vaan hän esiintyy eli mukana on taiteellinen ote. (Ks. kaavio 2.) Tämä tulee esille esimerkiksi seuraavassa haastatteluotteessa: 'Kansantanssia esitetään turisteille. Ne tanssijat harrastaa sitä ja harjottelee ja esittää sitte turisteille. Ne on sellaisia ohjelmanumeroita." 5

Osa informanteista eli 29 prosenttia korostaa kansantanssin ominaisuuksia luetellessaan perinteisyyttä koskevia aspekteja. Se, kuinka vanhaa tanssia pidetään perinteisenä, sen sijaan vaihtelee. Toisille riittävän vanhoja ja siten perinteisiä ovat vain ennen 1900 -lukua Suomeen tulleet tanssit. Toisille esimerkiksi suomalainen tanssilavakulttuuri on jo riittävän vanhaa ja perinteistä. Perinteinen tanssi voi olla esitettyä tai spontaania, tärkeintä on kuitenkin tanssin ikä. (Ks. kaavio 2.) Osa informanteista korostaa kansantanssin olevan jäänne vanhasta. Toisille se on aikansa elänyttä "tuohivirsukulttuuria". Toisille perinne on tärkeää taitotietoa. Heidän mielestään on hyödyllistä tietää, millaista oli ennen. Eräs informantti sanoo saman asian seuraavasti: 'Kansantanssit ovat vanhoja, jo vuosisatoja hioutuneita tansseja. Ne on paikallista perinnettä ja paikallisuutta tuodaan esille pitäjäkohtaisilla puvuilla".

\section{Etninen ja rahvaan tanssi}

Osa informanteista (31 prosenttia) korosti kansantanssin liittyvän kiinteästi jonkin ryhmän kulttuuriin. Oman tanssinsa avulla ryhmällä on mahdollisuus erottautua muista ryhmistä. Kansantanssia käytetään täten etnisen identiteetin rakennuselementtinä. Etnisyys-aspektin korostaja ei kiellä sitä, etteikö tanssi voisi olla myös estraditaidetta. Tanssi voi olla joko uusi tai vanha, mutta kansallispukujen käyttö koetaan tärkeänä. (Ks. kaavio 2.)

\footnotetext{
${ }^{5}$ Nauhat on litteroitu ja niitä säilytetään Tampereen yliopiston kansanperinteen laitoksessa. Nauhat on numeroitu KPL 10172-10183.
} 
Satunnaisotantaani osui myös tanssinharrastajia, joista eräs "tuottaa" etnisen tanssin seuraavasti: "Minulle kansantanssi on omilla juurilla oloa. Juuret on edellytys itsetunnolle ja identiteetille. Jos on juureton, niin sitä on heikoilla."

Osalle informanteista kansantanssi on nimenomaan kansan tanssimaa tanssia. Tutkijan oikeudella korvaan seuraavassa sanan kansa' sanalla 'rahvas'. 'Rahvas' - käsitettä on käytetty viittamaan oppimattomaan kansaan. Myös nykyrahvas on oppimatonta siinä mielessä, että tansseja ei välttämättä opetella, ainakaan "korkeakulttuurisesti". Osa informanteista katsoi kansantanssin olevan tanssia, jota ei opetella, vaan ne opitaan lähinnä matkimalla. Tanssi voi silloin olla uusi tai vanha, mutta olennaista on, että rahvas on sitä tanssinut tai tanssii tänä päivänä. (Ks. kaavio 2.) Näyttämölle nostettua tanssia ei tällöin välttämättä koeta kansantanssina, koska tavallinen rahvas ei niitä kykene tanssimaan niiden taitotanssiluonteen vuoksi. Näiden informanttien mielestä (24 prosenttia) kansantanssija on nimenomaan joko muinaisen, nykyisen tai tulevan kansan edustaja. Eräs informantti ilmaisi tämän seuraavasti: "kansantanssia on se, ku kansa tanssii omia tansseja omilla tanssipaikoillaan."

\section{Informanttien maailmankuvien pohjalta tehty typologia}

Jo haastatteluaineistoa kerätessäni oivalsin, että informantit puhuvat tanssista omaan maailmankuvaansa nojaten. Maailmankuva on hierarkkinen rakennelma. Musiikillinen ja tanssillinen maailmankuva ovat yleisen maailmankuvan hierarkkisen järjestelmän osarakenne, hänen musiikkiin ja tanssiin liittyvien käsitystensä kokonaisuus. Maailmankuvan ajatellaan sisältävän myös muita tiedollisia aineksia. Tiedollisten ainesten lisäksi maailmankuvassa nivoutuvat yhteen elämykset, uskomukset, arvot ja asenteet (ks. Karttunen 1990, 41-42). Kognitiivisen psykologian maailmankuvateoriassa maailmankuvalla tarkoitetaan yksilölle hänen kehityksensä myötä rakentuvaa "maailman sisäistä representaatiota", hänen omaa minää ja ulkomaailmaa koskevien käsitysjärjestelmien kokonaisrakennetta, jossa kiteytyneenä kuvastuu se, mitä hän on elämänsä aikana oppinut, ajatellut ja tuntenut (Takala 1982,68). Kognitiivisen psykologian maailmankuvateorian perustalta musiikillinen ja tanssia koskeva maailmankuva määrittyy siis yksilön maailmankuvan hierarkkisen järjestelmän osarakenteeksi, musiikkiin ja tanssiin liittyvistä tiedollisista käsityksistä, arvoista ja tunne-elämyksistä muodostuvaksi kokonaisuudeksi, joka ohjaa yksilön musiikillista ja tanssia koskevaa ajattelua ja harrastamista (vrt. Karttunen 1990, 42).

Luin haastattelupuhetta tanssillinen maailmankuva -paradigman näkökulmasta. Haastatteluaineisto näyttäytyi aluksi positiivisena ja negatiivisena tanssipuheena. Sekä positiivinen että negatiivinen suhtautuminen sisälsivät sävyltään kahdenlaista puhetta. Nimesin sävyt positiivisten osalta perinteiseksi ja moderniksi tanssia koskevaksi maailmankuvaksi. Kansantanssin suhteen kiel- 
teiset nimesin urbaaniksi ja uskovaisen ihmisen tanssia koskevaksi maailmankuvaksi. Seuraavaksi esittelen maailmankuvien lajeja kuitenkin informanttitypologian muodossa.

\section{Traditionalisti}

Perinteisesti asennoituvalle suomalaiset kansantanssit ovat tanhuja. Tanhut ovat vanhoja tansseja, joita harrastetaan. Kansantanssin harrastajat esittävät kansantanssia kansanjuhlilla kansallispukuihin pukeutuneina ja pelimannimusiikin säestyksellä. Ulkomaalaisilla on omat kansantanssinsa. Traditionalisti mainitsee oitis, että turistimatkoillaan hän on kokenut kansantanssiesitykset tärkeinä. Traditionalistien mielestä tällaiset paikalliset ja perinteiset tavat ovat arvokkaita. Kansantanssi siirtää ja säilyttää perinnettä. Perinne liittää yksilön sukupolvien ketjuun eli antaa jatkuvuuden tunnetta.

\section{Modernisti}

Modernistin ajattelussa kansantansseja tanssii kansa. 'Kansa' on eri kansakunnat tai etniset ryhmät, joilla on omat tanssinsa. Modernisti on kiinnostunut kulttuuri-ilmiöistä. Hän kokee eksoottiset elämykset arvokkaina. Modernistit tuntevat suomalaisten kansantanssien esityskäytännön ja kokevat esitykset tarpeellisiksi. He tiedostavat myös niiden syntyhistorian: suomalainen kansantanssi on nostettu näyttämölle siinä vaiheessa, kun haluttiin luoda suomalaiskansallinen identiteetti. Modernistit kokevat kuitenkin perinteet tärkeinä. Heidän mukaansa perinteet ovat "juurilla oloa". Modernistin mielestä tämän päivän varsinaisia suomalaisia kansantansseja ovat kuitenkin seura- ja diskotanssit. Kansantanssiesitysten tanssijat ovat puoliammattilaisia.

\section{Uskovainen}

Neljä informanttia satunnaisotannassani tunnustautuu uskovaisiksi. Heidän arvomaailmassaan tanssi on synnillistä toimintaa.

Heidän mielestään paritanssit ovat unelmatehtailua ja vahingollista ihmiselle. Tanssimiseen liittyy paljon huonoja lieveilmiöitä, varsinkin Suomessa. Kansantanssit ovat aikaisemmin olleet viatonta ilonpitoa. Nyt nekin on pilattu. Kansantanssi on esiintymistä eli tanssin avulla halutaan "päteä" ja hyötyä taloudellisesti. Tanssi ei kuulu kirkkoon. Vain pakanat voivat olla niin ajattelemattomia, että hyväksyvät tanssin uskonnon harjoitusmuodoksi. 


\section{"'Kaupunkilainen"}

Urbanisti ei ole juurikaan harrastanut tanssimista missään muodossa. Hän arvelee selviävänsä elämänsä läpi ilman tanssimista. Myöskään tanssiesitykset eivät ole saaneet häntä liikkeelle. Paritanssitaito on ainut tanssilaji, joka voisi häntä kiinnostaa. Suomalaista kansantanssia hän kutsuu tanhuksi. Tanhun hän liittää väyrysläisyyteen ja jättää tanhun mielellään heidän harrastuksekseen. Kansantanssi ei kuulemma ole "kolahtanut" hänen kohdallaan. Informantin mielestä kansantanssi on aikansa elänyttä "tuohivirsukulttuuria".

\section{Kansantanssin merkitykset, sitä koskevat maailmankuvat ja näkemykset 'meistä' ja 'muista'}

Edellä määrittelin, että kansantanssi on diskursiivista puhetta. Länsimaisessa ajattelussa kansantanssi-diskurssin sisältö on ennen kaikkea "me ja muut" -ideologiaa. Persoonallinen tai kansallinen identiteetti sisältää aina 'toisen'. Me määrittelemme siis itsemme suhteessa muihin ja myös kansantanssia käytetään apuna tällaisessa erontekoprosessissa. Seuraavaksi tarkastelen keräämääni kansantanssi-haastattelupuhettani esitelläkseni, miten informanttini tuottavat puheellaan meidän ja 'vieraiden' tanssillisia ominaispiirteitä.

Haastattelupuheesta oli osoitettavissa neljänlaisia kansantanssin sisältökorostuksia: estraditaide, perinteinen tanssi, etninen ja rahvaan tanssi. Estraditaide- ja perinteisyysaspektien korostajien puheesta on luettavissa rasistisia piirteitä. Heidän mielestään 'meidän' ja 'muiden' tanssit ovat erilaisia siten, että vain meidän tanssi arvotetaan taiteeksi tai taitotiedoksi, kun taas muilla tanssi on vain "nakuilua" (sambakarnevaali) tai osa arkiaskareita (afrikkalainen tanssi). Etnisyyden ja kansanomaisuuden korostajat lähestyvät sen sijaan tanssijoita tasa-arvoisesti. Heidän puheensa taustalta ei voi löytää arvottavasti erottelevaa lähtöasetelmaa.

Informanttien kansantanssipuheet näyttäytyivät tutkijalle maailmankuvallisina konseptioina. Nimesin konseptiot tanssia koskeviksi maailmankuviksi ja annoin suuntauksille nimet: perinteinen, moderni, uskovaisen ja urbaanin ihmisen tanssillinen maailmankuva. Edellisistä suuntautumisista on luettavissa egosentrisiä ja eurosentrisiä piirteitä. Uskovainen ja urbaani yksilö lähestyy tanssia itsekeskeisesti. Heidän ajattelussaan tanssi on nimenomaan heille itselleen joko vahingollista tai sitten merkityksetöntä. Moderni yksilö sensijaan tekee selvän eron 'meidän' ja 'muiden' kansantanssien välillä. Meidän tanssi eli lähinnä eurooppalainen kansantanssi on kyllä eksoottista, mutta se on tekemällä tehtyä. Sen sijaan ei-eurooppalaisilla on 'oikeaa' kansantanssia, jota kansa todella tanssii. Traditionalistin tanssia koskeva maailmankuva ei mielestäni sisällä 'meitä ja muita' arvottavasti erottelevia elementtejä. 


\section{Kirjallisuus}

Anttila, Jorma 1993. Käsitykset suomalaisuudesta - traditionaalisuus ja modernisuus. Teoksessa Mitä on suomalaisuus, toimittanut Teppo Korhonen. Jyväskylä: Gummerus.

Hall, Stuart 1992. The West and the Rest: Discourse and Power. Teoksessa Formations of Modernity, toimittaneet Stuart Hall ja Bram Gieben. Cambridge: Polity Press.

Hoerburger, Felix 1968. Once again: On the Consept of "Folk Dance". Journal of the International Folk Music Council Vol. 20: 30-33. Cambridge.

Karttunen, Sanna 1990. Musiikillisen maailmankuvan rakenne ja tyypit musiikkikirjastonhoitajilla. Etnomusikologian vuosikirja 1989-1990: 38-58. Jyväskylä.

Lehtonen, Mikko 1994. Me muissa: Babar unenamme. Teoksessa Me ja muut, toimittanut Marjo Kylmänen. Tampere: Vastapaino.

Merriam, Alan P. 1964. The Anthropology of Music. Evanston: Northwestern University Press.

Moisala, Pirkko 1988. Musiikkikulttuurin kognitiivinen viitekehys. Etnomusikologian vuosikirja 1987-1988: 142-155. Jyväskylä.

- 1991. Antropologinen musiikintutkimus. Teoksessa Kansanmusiikin tutkimus - Metodologian opas, toimittanut Pirkko Moisala. Helsinki: Valtion Painatuskeskus.

- 1993. Kulttuurisen musiikin kognitiivinen tutkimus. Musiikki 1-2/1993: 50-74. Helsinki.

Rantonen, Eila 1994. Länsimaisen estetiikan rasismi. Teoksessa Me ja muut, toimittanut Marjo Kylmänen. Tampere: Vastapaino.

Seppänen, Anne 1993. Kansantanssi puheena Suomessa 1990-luvulla. Pro gradu -tutkielma. Tampereen yliopiston kansanperinteen laitos.

Takala, Annika 1982. Maailmankuvan muodostumisesta. Kasvatus 1982: 2, 67-70. 